\title{
PHILIP V AND APOLLONIA IN 216
}

\section{Summary:}

In the summer of 216 Philip $V$ was about to attack Apollonia, but withdrew when he received the news that the Roman squadron was approaching. The immediate goal was to gain a suitable port for the war against Scerdilaidas, but the question is what were his long-term plans - expansion into Illyria, or war with Rome and an expedition to Italy. As for the second possibility, the main argument is the interpretation of Polybius, as well as the Roman reaction and perception of contemporaries of Philip and his ambitions. But in this case, the opinion of Polybius is not convincing, and the reaction of Rome shows the Roman point of view and not the plans of the Macedonian king, and the same could be said for the point of view of his contemporaries. Therefore, although a definitive answer is impossible, the first possibility seems more likely, especially if his actions in the next few years are taken into account. At first, he did not intend to go to war with Rome, but after the Roman reaction in 216, and especially after the catastrophe at Cannae, he turned to Hannibal. Yet even then his main target remained Illyria.

Keywords: Philip V, Scerdilaidas, Polybius, Illyria.

In the summer of $216,{ }^{1}$ at the head of a new fleet of 100 lembi, Philip $\mathrm{V}$ sailed to Apollonia. After a brief halt at Cephallenia and Leucas, once being informed that the Roman fleet is still anchored at Lilybaeum, he proceeded on his way. But just as he was approaching the mouth of r. Aous, the news came that a Roman squadron was coming to Scerdilaidas' aid, at which point he retreated in panic. ${ }^{2}$ What exactly was Philip trying to achieve and what was his ultimate goal - the subjugation of Scerdilaidas, or perhaps an opening phase of a grander scheme? As expected, historians are divided on the issue. ${ }^{3}$ Since Philip never got a chance to realize his original goals, all of the offered solutions are speculation to some degree. Still, few would disagree if we say that, at least in 216, Philip's actions point to a conclusion that his immediate aim was Illyria, that is Scerdilaidas. Therefore a brief review of their relation during the Social War is in order.

1. In the decade after 230, from a subordinate to Agron and Teuta, Scerdilaidas rose to prominence as one of the most powerful Illyrian dynasts - sec${ }^{1}$ All dates are BC.

${ }^{2}$ Polyb., 5.109.4-110.6.

${ }^{3}$ e.g.Walbank (1940), 69; Id. (1993), 1723; Rich (1984), 129-30; Eckstein (2008), 80-1, initial phase in grander conquests; Gruen (1984), 374-5; Adams (1993), 45; Champion (1997), 118-21, ambitions limited to Illyria. 
ond, or perhaps even equal, to Demetrius of Pharos. ${ }^{4}$ In 220 they ventured on a joint grand pirate campaign that started with an unsuccessful attack on Pylos, at which point Demetrius moved on to the Cyclades, while Scerdilaidas struck a deal with the Aetolians. Deceived by them, he quickly switched sides and made an alliance with Philip. However, this time both of them failed to fulfill what was agreed - neither Philip paid the promised amount, nor did Scerdilaidas send the expected number of ships. In response, Scerdilaidas sent 15 lembi which managed to capture four of Philip's ships and subsequently engaged in pillaging and looting along the coast. With a hastily assembled fleet, Philip tried ultimately but failed to catch the Illyrians. ${ }^{5}$

These incidents were just the beginning of the hostilities. Counting on Philip's involvement in the Social War, Scerdilaidas invaded Pelagonia and Dassaretis, where he managed to capture a number of cities. ${ }^{6}$ What he did not know was that at the same time the peace of Naupactus was being concluded which ended the Social War. ${ }^{7}$ Freed from his engagements in Greece, Philip launched a lightning counterattack, managed to regain the lost cities, and established control on the area from Lychnidus to the Caloecini, at which point he disbanded the army. ${ }^{8}$ It was after the conclusion of this campaign that Philip, in the winter of $217 / 6$, decided to build a fleet of 100 lembi.

2. This summary of events gives the impression that the new fleet was meant for fighting Scerdilaidas. A small fleet of 100 lembi was ill-suited for opposing the Roman quinqueremes, as Polybius himself points out; ${ }^{9}$ it was intended primarily for operations in Illyria. The events of the next few years point to a similar conclusion - in the treaty with Hannibal, the ambitions of Philip (and Demetrius of Pharos) are confined to Illyria, while any Macedonian aid to Italy would be sent only at Hannibal's request. ${ }^{10}$ After the fiasco at Oricum and Apollonia in 214, Philip neither had, nor attempted to build a new sizeable

\footnotetext{
${ }^{4}$ For Scerdilaidas up until 220 v. Šašel Kos (2002), 146-8, though some of her assumptions can not be corroborated in the sources.

${ }^{5}$ v. Šašel Kos (2002), 148-50; Пановски (2014), 245-8.

${ }^{6}$ Polyb., 5.108.1-2.

${ }^{7}$ Polyb., 5.103.1-8.

${ }^{8}$ Polyb., 5.103.8-9. Hammond (1968), 15-6; Id. (1972), 94-5.

9 5.109.1-3.

${ }^{10}$ Polyb., 7.9. Bickerman (1944); Id. (1952); Walbank (1967), 42-56; Errington (1989), 96-7; Adams (1993), 47-8. contra e.g. Seibert (1995), 240 and especially Eckstein (2008), 85, according to whom the provisions of the treaty leave open the possibility for an invasion

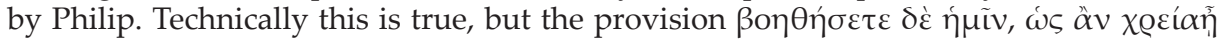

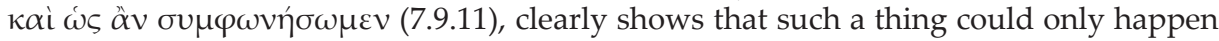
at the request of Hannibal. Whether this meant that Philip would personally come or just send auxiliary detachments, this is very different from the Italian campaign that Philip allegedly dreamed of.
} 
fleet, ${ }^{11}$ and spent the next few years conquering the interior of Illyria, culminating with the fall of Lissus. ${ }^{12}$

So far no indication of the alleged plan to invade Italy. Now, one could remark that the events after 216, and especially after 214, are irrelevant for the initial plans of Philip, for in the meantime the situation changed dramatically, ${ }^{13}$ which is essentially true. Moreover, this is not the conclusion of Polybius, who considered these operations to be merely an introductory phase of plans far more ambitious ${ }^{14}$ - a conclusion accepted by a number of scholars. On what arguments does this assumption rest?

3. Apart from Polybius's authority, the main argument seems to be the opinion of Philip's contemporaries and the Roman response to the alliance with Hannibal, and, of course, the seemingly unexpected end of the Social War. As for the Peace of Naupactus, it may seem unexpected only if we accept Polybius' account and interpretation; on the contrary, from the course of the war, Philip must have realized that he no longer had anything to gain from the conflict, which was not his choice anyway. ${ }^{15}$

As for the Romans, they undoubtedly feared a possible attack by Philip, but only after they discovered the treaty with Hannibal in 215. The only previous measure was the stationing of 25 ships tasked with protecting the coast between Tarentum and Brundisium. ${ }^{16}$ Even the measures of 215 are somewhat moderate and certainly do not indicate excessive anxiety, much less panic in Rome - the fleet was reinforced with 30 more ships, and the praetor Valerius Laevinus was ordered to closely monitor the events and intervene only if it seemed that Philip did indeed plan to link up with Hannibal. ${ }^{17}$ In fact, Polybius mentions the fear of Philip only a few times, but given the fragmentary state of his work, this argument should not be pressed too far. Livy cites more

\footnotetext{
${ }^{11}$ Holleaux (1921), 159 n.2. In 207 Philip started building a new fleet (Liv., 28.8.14), but it looks like the project was soon abandoned (Holleaux (1921), 246 n.2). Although the construction of 100 polyremes (naves longae) was planned, at the Battle of Chios, six years later Philip had only 53 cataphracts (Polyb., 16.2.9), after reinforcing his fleet with a number of ships he had seized at Samos. In any case, the decision in 207 certainly cannot be understood in the context of a plan for a future campaign in Italy, but rather as an attempt to establish local naval dominance in the war against Rome and the Roman allies (cf. Liv., 27.30.16). According to Kleu, the new fleet was partially finished, but was not meant for fighting Rome, but represented the beginning of the plans for the Aegean expansion (Kleu (2015) non vidi, apud Nicholson (2017)).

12 On these events, $v$. Walbank (1940), 80-1; Hammond (1988), 398-9. According to Hammond (loc. cit.), after the fall of Lissus, Philip started building a new fleet there, accepted by Eckstein (2008), 87. But this theory, based on the numismatic evidence and one problematic information from Zonaras (9.6), has been refuted by Kleu (2017).

${ }^{13}$ cf. Walbank (1940), 71.

${ }^{14}$ Polyb., 5.108.3-7.

${ }^{15} \mathrm{v}$. Пановски (2020), with the pertinent literature.

${ }^{16}$ Liv., 23.32.17. Errington (1989), 96, is probably correct in assuming that the main cause was the threat of the Carthaginian fleet, and not from Philip.

${ }^{17}$ Liv., 23.38.7-11.
} 
examples where the Roman aim is to prevent an invasion by Philip, but as Rich points out, this narrative is contaminated by annalistic influences, and therefore of doubtful value. ${ }^{18}$ Of course, this does not mean that one should embrace the other extreme and maintain that Rome did not fear Philip at all, especially in the first days after discovering the treaty with Hannibal. ${ }^{19}$ The 50 ships sent by the Senata may not seem impressive and probably indicate that the Senate was not all too upset by the treaty after correctly assessing Philip's capabilities, ${ }^{20}$ but at the same time, we should bear in mind that we are dealing with the period after the disaster at Cannae, when Roman resources were strained to the extreme. Though remote, the possibility of an invasion was not non-existent. ${ }^{21}$ But in the end, all this does is show the Roman fears and their assessment of the situation, ${ }^{22}$ and not the plans of Philip himself.

The information that at one point even Syracuse hoped to get help from Philip should be interpreted similarly. ${ }^{23}$ Had Philip responded to this request, then we would finally have at least one direct indication of his intentions, but the envoy was captured and never reached the king. Thus, once again we are dealing with other people's perception of Philip and his ambitions, and not with an action or statement of the king; we should also have in mind that at the time Syracuse was under siege by Claudius Marcellus.

\footnotetext{
${ }^{18}$ Rich (1984), 162 n.48. The annalistic tradition in Livy (24.13.5), that Hannibal wanted to conquer Tarentum because it was a convenient port for Philip to land, should be similarly assessed. As for Polybius, Rich cites three examples: 5,105.8, 8.1.6, and 9.22.5. But on 8.1.6, Polybius simply mentions the action of the fleet against Philip. 9.22.5 is part of an assessment of Hannibal's character, and though he points out the Roman fear, it is in the context of the main threat coming from the Carthaginian, while Philip is rather a "diver-

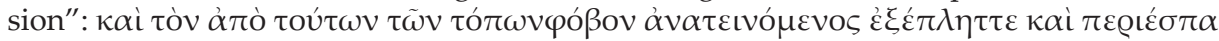

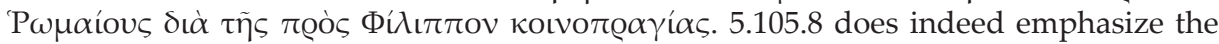

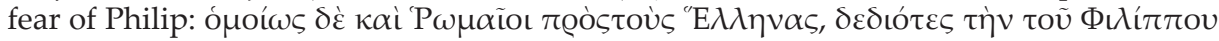

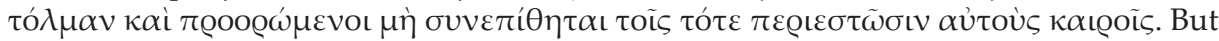
this is in the context of the beginning of symploke - an analysis that is somewhat problematic. $v$. Walbank (1975), 199-203; the explanation of Eckstein (2008), 82, is not convincing. In any case, what is important for us, is that in the period immediately before and after the peace at Naupactus, no Roman envoys are attested in Greece arguing against Philip, which greatly reduces the value of Polybius' interpretation.

${ }^{19}$ But, after the fiasco in 214, they must have realized that Philip posed no direct threat to Italy, if he ever was to begin with. cf. Harris (1979), 205-6.

${ }^{20}$ Errington (1989), 97-8.

${ }^{21}$ It may seem that the Roman response to these successes, i.e. their alliance with the Aetolians (Liv., 26.24.7-15; Moretti II.87), points to a renewed fear of Philip, but more likely it indicates an attempt to limit the local successes of the Macedonian king, and to maintain the Roman authority and control of the Adriatic. cf. Gruen (1984), 17-21, 377-9; Errington (1989), 98-101.

${ }^{22}$ At the same time we should bear in mind the permanent psychological scar left by the war with Pyrrhus. Seibert (1995), 237-8; Eckstein (2006), 156.

${ }^{23}$ Liv. (P), 25.23.8-9. Though some doubt the veracity of the information, in itself it is not impossible (Rich (1984), 130; Eckstein (2008), 87).
} 
We are left with the interpretation of Polybius, whose opinion is always worthy of attention. According to his version of the story, the young and ambitious Philip, whose hopes were fired up by Demetrius of Pharos (and additionally by Agelaus' speech at Naupactus), dreamed of world conquest, and Illyria was only the first step in fulfilling this plan. ${ }^{24}$ What must be taken into account is that the analysis of Philip's policy in this period is only one segment of the complex and generally negative image of the Macedonian king that Polybius paints throughout his work - from a young, promising and gifted ruler, Philip's character gradually deteriorates and he eventually ends up as an almost halfmad tyrant. ${ }^{25}$ In this context, it should be noted that the desire for world power, or at least for extensive conquests, is not restricted to the period up to 214, but is present as well in his plans during the Eastern policy of 204-200, i.e. until the Second Macedonian War - on this issue Polybius is quite consistent. However, in several instances, his conviction leads him to questionable conclusions.

Thus, according to Polybius, because of his panic retreat, Philip missed the best opportunity to conquer Illyria. ${ }^{26}$ This conclusion appears to be unconvincing and somewhat unfair. Unconvincing, for it is questionable whether Philip truly hoped to conquer Illyria with only 100 lembi and approximately 5000 soldiers. ${ }^{27}$ Unfair, because it ignores the strategic and logistical difficulties that Philip would have faced if he did engage the Roman squadron, ${ }^{28}$ and possibly Scerdilaidas as well. ${ }^{29} \mathrm{~A}$ similar conclusion may be drawn from the analysis

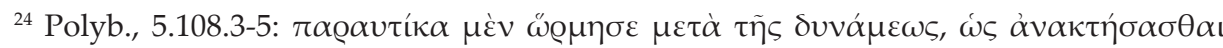

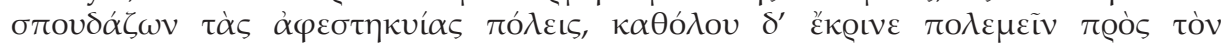

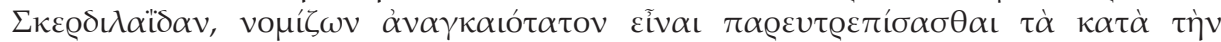

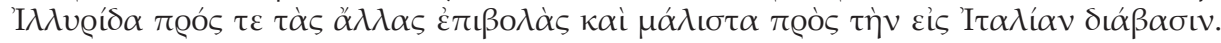

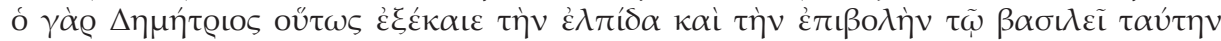

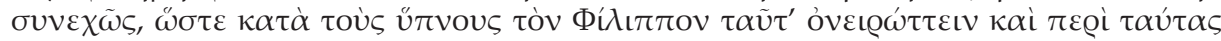

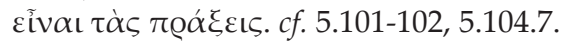

${ }^{25} v$. Eckstein (1995), passim, and some of the papers in Gibson \& Harrison (2013), where the most important works on the subject are cited.

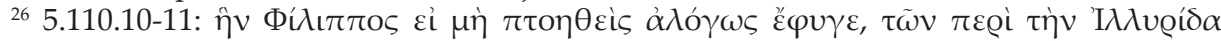

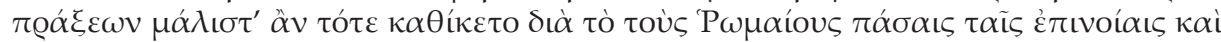

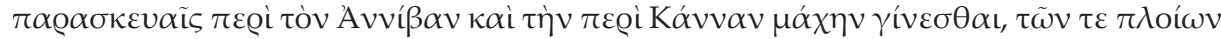

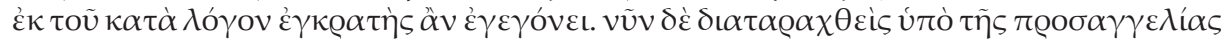

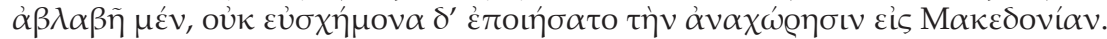

${ }^{27}$ Polybius himself states that the main role of the fleet was transporting troops and thus facilitating fast and sudden attacks. (5.109.2). This is more reminiscent of the campaign of 218, which culminated with the blitz on Thermum, (Walbank (1940), 52-6; Hammond (1988), 379-80), rather than a plan to conquer Illyria.

${ }^{28}$ Holleaux (1921), 178 n.1; Hammond (1988), 392-3. Additionally in Philip's defense should be added the fact that his fleet was inexperienced, since it was only in 216 that the Macedonians practiced as rowers (5.109.4). The fact that the Macedonians were rowers is perhaps one of the key reasons in the decision to withdraw - the reluctance to risk the lives of Macedonian soldiers in a naval battle, where serious losses could be expected in the clash with the Roman quinqueremes.

${ }^{29}$ In his analysis Polybius does not mention Scerdilaidas, whose whereabouts at this point are unknown. According to Polybius, Philip received the news ö $\tau \iota ~ \kappa \alpha \tau \alpha \lambda \varepsilon i ́ \pi o เ \varepsilon v$ 
of the situation after the battle of Lade in 201, when, according to Polybius, Philip acted like a madman ( $\mu \alpha v \iota \omega \delta \eta \gamma \gamma \varepsilon v o ́ \mu \varepsilon v o v)$ not setting sail for Alexandria even though the way was open. ${ }^{30}$ Irrespective of the chronological sequence of the battles at Chios and Lade, Polybius' assumption is, to put it mildly, unrealistic - with no harbor under his control, extended lines of communication, and an enemy fleet (possibly two) behind him, Philip could hardly have been thinking of, let alone actually setting sail for Egypt. ${ }^{31}$ The theory that the roots of the Third Macedonian War should be sought in the policies of Philip in the last decade of his reign hardly deserves mention. ${ }^{32}$

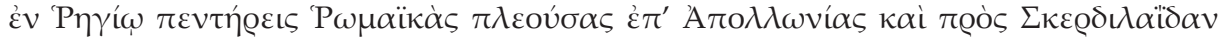
(5.110.3), which implies that Scerdilaidas was somewhere near Apollonia. As it turned out, the task of the Roman squadron was reconnaissance and does not seem to have involved cooperation with Scerdilaidas, but Philip could not have known this for sure and had to consider such a possibility, in which case his chances of success would have been even more reduced. cf. Adams (1993), 46-7.

${ }^{30}$ 16.10.1, with Walbank (1967), ad loc.

${ }^{31}$ De Sanctis (1923), 10-12; Hammond (1988), 415-6. In a detailed analysis of the "predatory pact" and the events of 201-200, Eckstein (2008), 139-180, attempts to prove that Polybius' interpretation is sound. On this occasion we can not dwell in detail on the whole argument, but a few points deserve a brief mention. As for the historicity of the treaty between Philip and Antiochus III 203/2, the question can now be taken as resolved - there undoubtedly was some sort of agreement. Eckstein is also right when he insists that there is no basis for emending Polybius's text and that, at least in his version, Egypt should have belonged to Philip. But what of it? Unlike the agreement between Philip and Hannibal, in this case, at least according to the indications in the preserved part of his work, Polybius probably did not see the official document, so the exact provisions were probably subject to various suppositions and speculations, but also exaggerations. cf. Walbank (1967), 472; Ma (1999), 74-6. Therefore, his testimony here does not carry the same weight as in the case of Philip and Hannibal. It is also undeniable that the Ptolemaic state was going through a serious crisis, which would have facilitated the eventual conquest of Egypt. But on the other hand, he seems to underestimate the challenges Philip would have faced in trying to get to Egypt - from logistical problems to the fact that the long absence of the king and part of the army would expose Macedonia to a potential attack by neighboring tribes who usually did not fail to take advantage of such opportunities. Not to mention the possible reaction of Antiochus III, whose main bases were incomparably closer to Egypt, and thus would have had a huge advantage in a possible conflict with Philip - just because an agreement was reached does not mean that either side was prepared to honor it in the long term (cf. Polyb. 16.20.6). Of course, the analysis loses almost any value if the battle of Chios preceded that of Lade, but since the sequence of events in 201 is not entirely clear this argument is not conclusive; but even in the opposite case, Philip would have had to count on the uninterrupted action of the Rhodian fleet in his rear which could have had catastrophic consequences, as the winter of 201/200 which he was compelled to spend in Bargylia, will soon show. Therefore, Eckstein is certainly right when he insists that Philip was known for his daring and risky undertakings, but such a venture could be characterized as madness rather than risk.

${ }^{32}$ Polyb., 22.18.10-11. In fact, the theory is repeated several times in Polybius and in the ancient tradition in general (v. Burton (2017), 91 n.63). Eckstein (1995), 215, points out that Polybius criticizes Philip because his policies were unrealistic and led to the fall of 
These examples show that, at least when it comes to Philip's motives and ultimate goals, Polybius' analysis must be taken with a great deal of reservation. Of course, this does not mean that Philip was not an extremely ambitious and aggressive ruler - this is demonstrated by many of his actions, especially in the period $220-200 ; 33$ or that he did not dream of fame and world conquests - a feature he shares with many rulers of the Hellenistic period. ${ }^{34}$ This was all the more important for Philip V, whose dynasty considered itself a direct successor and relative of the Argeads, and whose role model was Philip II. ${ }^{35}$ But it is much more difficult to discern what in here is propaganda, ${ }^{36}$ what are day-dreams, and what he considered to be realistically achievable goals. As Errington concludes in his analysis of a problem similar to ours: nothing of course prevents a king from day-dreaming, or a historian from day-dreaming about a king's daydreams; but it is not helpful to pretend that in this way we can reach certainty. ${ }^{37}$ Therefore, it would be best to analyze Philip's motives in 216 solely on the basis of the events in that year.

4. In this context, it is not surprising that Philip decided to attack Apollonia first ${ }^{38}-$ he needed a convenient harbor from which to launch operations against Scerdilaidas, and at the same time relatively close to his domains in Dassaretis. ${ }^{39}$ The fact that Apollonia was independent and neutral meant little to him, as some of his actions in the period 202-200 will show..$^{40}$ Whether Philip had bigger plans for Illyria is unclear, but seems probable. ${ }^{41}$ This was due to

the Antigonids. But the problem is not the critique itself, but the assumption on which it rests - that Philip's policy, which Perseus only followed, is the real cause of the war; which is highly debatable for several reasons. e.g. Harris (1979), 227-33; Burton (2017), 91-96.

${ }^{33}$ The best testimony for the reputation of Philip is certainly the epigram of Alcaeus of Messene (Anth. Pal., 9.518), irrespective of the fact that it is probably hostile and utterly ironic.

${ }^{34}$ v. Austin (1986); Eckstein (2006), ch. 4.

${ }^{35}$ Errington (1976), 153-4; Walbank (1993), 1725-9.

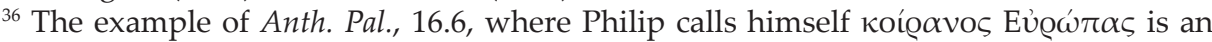
interesting one. But this dedication requires further analysis, because it is not entirely clear what the message is and for whom it is intended for.

${ }^{37}$ Errington (1981), 79.

${ }^{38}$ Badian (1952), 89, speculates that Philip may not have planned to attack Apollonia in 216, and that his only target was Scerdilaidas. Similarly Adams (1993), 46, who points out that Polybius' language does not imply hostile intentions towards Apollonia. Though not impossible, the suggestion is not convincing given the logistical challenges Philip would have faced while operating in the Adriatic without a single seaport under his control and with extremely long lines of communication. $v$. Hammond (1968), 17 n.59.

${ }^{39}$ Hammond (1968), 16-7.

${ }^{40}$ Especially the examples of Cius (Polyb., 16.21-23.6. Steph. Byz., s.v. Пஹoṽ $\sigma \alpha$ ), Myrleia (Strabo, 12.4.3; Hermippus, FHG III, frg. 72 (p.51); Steph. Byz., s.v. Mú@ $\lambda \varepsilon \iota \alpha$ ), Thasos (Polyb., 15.24.1-3. cf. Liv., 33.30.3) and Abydus (Polyb., 16.29.3-34; Liv., 31.16.7-18).

${ }^{41}$ As shown, among other things, by the provisions of the agreement with Hannibal (Polyb., 7.9.12-14.). 
several factors - the influence of Demetrius of Pharos, ${ }^{42}$ the desire for conquest, but also the realization that the policy of cooperation with the Illyrian dynasts, initiated by Antigonus Doson, brought neither stabilization nor resolution of the problems on the northwestern border. ${ }^{43}$ The desire to emulate his role model, Philip II, whose reign was associated with the Macedonian expansion (and control) in Illyria was probably an additional motive. ${ }^{44}$ The wisdom of such a policy is another matter entirely. ${ }^{45}$

But what about Rome? The answer to this question largely depends on the nature of Roman presence in Illyria in the previous decades. The sources, appear to suggest that we should reject the theory of a formal or informal Roman protectorate in Illyria. ${ }^{46}$ The Romans concluded a series of treaties of amicitia and that was it - there were no Roman garrisons, no magistrates, and

${ }^{42}$ On several occasions Polybius emphasizes the influence of Demetrius of Pharos, and there is no need to doubt that, especially since he, that is his interests, are directly mentioned in the agreement between Philip and Hannibal. (Polyb., 7.9.14). But whether that means that he was also the creator of Philip's plans and goals is a completely different question. Walbank (1940), 261-2, noted long ago that Philip's new initiatives coincided with the rise to prominence of a new adviser, but concluded that there was no tangible evidence that he was at any time a tool in the hands of these advisers. According to O'Neil (2003), 515-7, the presence and prominence of multiple foreigners could be understood as a weakness on Philip's part. A conclusive answer is impossible, especially since it seems that the sources overestimate the importance and influence of these advisers, including that of Aratus the Elder. The persistence with which Philip pursued the Illyrian policy even in the period after the death of Demetrius of Pharos leaves the impression that he was after all the main creator of the new political activisms. In that context, the emergence of new advisers exactly when Philip was developing new plans could be interpreted as an attempt by the king to find associates who did not enjoy traditional support in Macedonia, and whose status depended solely on him, making them obedient followers; as opposed to the traditional Macedonian aristocracy from where one could expect greater resistance in developing new and risky plans. If this assumption is correct, this approach would be at least partially conceived under the influence of the events of 218, i.e. the confrontation with Antigonus Doson's old associates.

${ }^{43} \mathrm{cf}$. Dell (1970), 120; Пановски (2014), 247-9. Especially since this time it was a matter of a former ally and member of the Symmachy - Philip could not allow such a challenge to his authority as the hegemon of the alliance to go unanswered.

${ }^{44} \mathrm{cf}$. Champion (1997), 120, based on Isoc., Phil., 21. That the depiction of Isocrates is somewhat exaggerated (cf. Griffith (1979), 469-72); Кабан (1996), 80-3), does not affect the assumption that Philip V would have liked to imitate his famous namesake. On the contrary, it would be an additional incentive to even surpass Philip II's achievements in that region.

${ }^{45}$ cf. Bickerman (1952), 20-21; Errington (1989), 94.

${ }^{46}$ There is a long scholarly debate concerning the nature of the roman presence in Illyria after the First Illyrian War. Here in general is accepted the interpretation of Eckstein. For various interpretations v. Holleaux (1928) 835-7; Badian (1952), 78-81; Petzold (1971), 206, 220-1; Derow (1991); Eckstein (1999); Id. (2008), 42-58; Burton (2011), 136-41. The attempt of Potter (2012), to prove that part of the land after the First Illyrian War was ager publicus, as shown by the treaty of Philip and Hannibal is unconvincing to say the least. ( $v$. Eckstein (2012), 356-8). 
no administration in Illyria. That they considered Illyria to be in their sphere of interest and influence is certain, as they proved in 216, but up until that time their interests had not been formalized. Therefore, there is no need to interpret Philip's policy in 216 as the first step towards war with Rome. He certainly understood that he was about to penetrate the Roman sphere of interest, ${ }^{47}$ but that did not have to be a reason for war, especially since Illyria could neither be considered Roman territory nor did the Romans have any official allies there. He clearly miscalculated that in the face of Hannibal's recent victories, the Romans would either show no inclination or simply lack the means to defend their interests on a secondary front. We can only speculate what his next steps would have been if the situation remained unchanged, can only be speculated. However, after the disaster at Cannae, the situation dramatically changed and he turned to Hannibal. Nonetheless, as the treaty shows, both Hannibal and Philip expected the war to end soon. In that sense, the alliance was more about securing Macedonian interests in Illyria and defining spheres of influence in the post-war period, rather than an agreement of immediate military cooperation. ${ }^{48}$

Philip's immediate goal in 216 was Apollonia and the war with the Illyrian ruler, probably as the first step of a future Macedonian expansion into Illyria. None of Philip's actions suggests that his eventual long-term aims were Rome and Italy. But the Roman reaction, no matter how symbolic, nonetheless showed that in the event of an expansion into Illyria, Philip would have to take into account Roman intervention, so he turned to Hannibal. Contrary to their expectations, Rome did not surrender, the Punic War continued, and Philip only later felt the consequences and paid the price for his ambitions and the decision to take advantage of the momentary weakness of the Republic.

\footnotetext{
${ }^{47}$ According to Polybius (5.109.5-6), Philip waited in the vicinity of Cephallenia and Leucas, until he discovered the whereabouts of the roman fleet. This shows that he was aware that his actions might provoke a roman reaction.

${ }^{48}$ Bickerman (1952), 21-4; Errington (1989), 96-7; Adams (1993), 48-9.
} 


\section{References:}

Adams, W. L. (1993). „Philip V, Hannibal and the Origins of the First Macedonian War". AM 5, 41-50.

Austin, M. M. (1986). „Hellenistic Kings, War, and the Economy“. CQ 36, 450-66.

Badian, E. (1952). „Notes on Roman Policy in Illyria (230-201 B.C.)“. PBSR 20, 72-93.

Bickermann, E. (1944). „An Oath of Hannibal“. TAPA 75, 87-102.

Bickermann, E. (1952). „Hannibal's Covenant”. AJPh 73.1, 1-23.

Burton, P. J. (2011). Friendship and Empire: Roman Diplomacy and Imperialism in the Middle Republic (353-146 BC). Cambridge: Cambridge University Press.

Burton, P. J. (2017). Rome and the Third Macedonian War. Cambridge: Cambridge University Press.

Champion, C. (1997). „The Nature of Authoritative Evidence in Polybius and Agelaus' Speech at Naupactus". TAPA 127, 111-28.

Dell, H. J. (1970). „The Western Frontiers of the Macedonian Monarchy“. AM 1, $115-26$.

Derow, P. S. (1991). „Pharos and Rome“. ZPE 88: 261-70.

De Sanctis, G. (1923). Storia dei Romani, 4.1. Torino: Fratelli Bocca.

Eckstein, A. M. (1995). Moral vision in the Histories of Polybius. Hellenistic culture and society. London: University of California Press.

Eckstein, A. M. (1999). „Pharos and the Question of Roman Treaties of Alliance Overseas in the Third Century BC". CPh 94, 395-418.

Eckstein, A. M. (2006). Mediterranean Anarchy, Interstate War and the Rise of Rome. Berkeley: University of California Press.

Eckstein, A. M. (2008). Rome Enters the Greek East. From Anarchy to Hierarchy in the Hellenistic Mediterranean, 230-170 BC. Malden, MA; Oxford; Chichester: Wiley-Blackwell.

Eckstein, A. M. (2012). „Review-Discussion: Polybius, the Greek World, and Roman Imperial Expansion“. Histos 6, 350-358.

Errington, R. M. (1976). "Alexander in the Hellenistic World“. In E. Badian (ed.), Alexandre le Grand. Image et réalité. Fondation Hardt, Entretiens 22. Vandouevres-Genève, 137-179.

Errington, R. M. (1981), „Review-Discussion: Four Interpretations of Philip II“. AJAH, 69-88.

Errington, R. M. (1989). „,Rome and Greece to 205 BC.“. in CAH² VIII, 81-106.

Gibson B. \& Harrison T. (eds.). (2013). Polybius and his World: Essays in Memory of F. W. Walbank. Cambridge and New York: Cambridge University Press.

Griffith, G. T. (1979). N. G. L. Hammond \& G. T. Griffith, A History of Macedonia, vol.2. Oxford: Clarendon Press.

Gruen, E. S. (1984). The Hellenistic world and the coming of Rome. Berkeley-Los Angeles-London: University of California Press. 
Hammond, N. G. L. (1968). „Illyris, Rome and Macedon in 229-205 B.C.“. JRS $58.1-2,1-21$.

Hammond, N. G. L. (1972). A History of Macedonia, vol.1. Oxford: Clarendon Press.

Hammond, N. G. L. (1988). N. G. L. Hammond \& F. W. Walbank, A History of Macedonia, vol.3. Oxford: Clarendon Press.

Harris, W. V. (1979). War and Imperialism in Republican Rome, 327-70 B. C. Oxford: Clarendon Press.

Holleaux, E. (1921). Rome, la Grèce et les monarchies hellénistiques au IIIe siècle avant J. C. (273-205). Paris: E. de Boccard.

Holleaux, M. (1928). „The Romans in Illyria“, in CAH VII: 822-57.

Кабан, П. (1996). За Илирите од Бардилис до Гентиј. Скопје: Догер.

Kleu, M. (2015). Die Seepolitik Philipps V. von Makedonien. Bochum: Verlag. (non vidi)

Kleu, M. (2017). „Philip V, the Selci Hoard and the supposed building of a Macedonian fleet in Lissus“. AHB 31, 112-119.

Ma, J. (1999). Antiochos III and the cities of Western Asia Minor. Oxford: Oxford University Press.

Nicholson, E. (2017). Review of Kleu (2015). @ https://bmcr.brynmawr. $\mathrm{edu} / 2017 / 2017.08 .29 /$

O' Neil, J. L. (2003). „The ethnic origins of the friends of the Antigonids“. CQ n.s. $53.2,510-522$.

Пановски, С. (2014). „Македонско-идирските односи кон крајот на III век ст.е.“. In М. Јакимовска-Тошиќ (ур.), Македонско-хрватски книжевни, културни и јазични врски. Скопје: Институт за македонска дитератуpa, 237-259.

Пановски, С. (2020). „Кобниот совет на Агелај - The baneful advice of Agelaos". Годишен зборник на Филозофскиот факултет 73, 125-140.

Petzold, K.-E. (1971). , Rom und Illyrien: Ein Beitrag zur römischen Außenpolitik im 3. Jahrhundert". Historia 20.2/3, 199-223.

Potter, D. (2012). „Old and New in Roman Foreign Affairs. The Case of 197". In C. Smith and L. M. Yarrow (eds.), Imperialism, Cultural Politics, \& Polybius. Oxford and New York: Oxford University Press, 134-151.

Rich, J. W. (1984): „Roman Aims in the First Macedonian War“. PCPhS 210, 12680.

Šašel Kos, M. (2002). „,From Agron to Genthius: large scale piracy in the Adriatic“. In L. Bracessi and M. Luni (eds.), I Greci in Adriatico 1, (Hesperia: studi sulla grecità di occidente 15). Roma: L' Erma di Bretschneider, 137-55.

Seibert, J. (1995). „Invasion aus dem Osten: Trauma, Propaganda, oder Erfindung der Römer?". In Schubert, C. et al. (eds.). Rom und der griechischen Osten: Festschrift für H. H. Schmitt. Stuttgart: Franz Steiner Verlag, 237-248.

Walbank, F. W. (1940). Philip V of Macedon. Cambridge: Cambridge University Press. 
Walbank, F. W. (1967). A Historical Commentary on Polybius, vol.2. Oxford: Clarendon Press.

Walbank, F. W. (1975). „Symploke: its role in Polybius' Histories“. Yale Classical Studies 24, 197-212.

Walbank, F. W. (1993). "H T $\Omega$ N O $\Lambda \Omega N$ E $\Lambda \Pi I \Sigma$ and the Antigonids“. AM 5, 1721-30. 